\title{
CONSTRAINTS OF GEOGRAPHY TEACHER OF SMA N 1 NGAGLIK IN DEVELOPING THE 2013 CURRICULUM LEARNING DEVICES IN SLEMAN REGENCY
}

\author{
Fajar Agung Nugroho ${ }^{1}$ and Hastuti ${ }^{1}$ \\ ${ }^{1}$ Geography Education, Postgraduate Program, Yogyakarta State University, Caturtunggal, \\ Depok, Sleman, Yogyakarta \\ Email: fajar.agung2016@student.uny.ac.id
}

Received 29 December 2018/ Revised 10 February 2019/ Accepted 12 February 2019/ Published Online 29 April 2019

\begin{abstract}
The study aimed to find out: (1) the difficulties of geography teachers Of SMA 1 Ngaglik in developing the learning devices, and (2) their efforts to overcome them. The research conducted in SMA N 1Ngaglik used the descriptive qualitative methods, meanwhile the subjects were geography teachers. The data collection techniques were observation, interviews, and documentation. The data analysis technique used the interactive analysis which included data collection, data reduction, data presentation and conclusion withdrawal. The results of this study indicated that (1) the constraints encountered by them were regarding the development of syllabus using a scientific approach; they had not carried out all learning models in accordance with 2013 Curriculum, difficulties in developing learning media, developing the teaching materials, and assessing the attitudes and skills balanced with the knowledge, and (2) efforts to overcome the difficulties that was the teachers performed the various ways: discussing and sharing with the other geography teachers, participating in MGMP activities from the school level until the district one, attending training or workshops to add insight and various knowledges for improving the development of learning devices.
\end{abstract}

Keywords: Constraints, Learning Devices, 2013 Curriculum

\section{Introduction}

Human resources are the goal of every nation. These goals can be achieved including through education. It is developed continuously along with the development of civilization, science, technology, and art. The continuous effort to improve the quality of education is manifested in the form of curriculum changes.

The curriculum changes from time to time have the clear reasons and basis. Thechanges are encouraged by the desire to continue and to improve the quality of the 
national education system. The teachers as the spearhead in curriculum implementation is demanded to optimally and seriously understand and apply it because the quality of the implementation of the education process is seen from this.However, in the field, the curriculum changes frequently create some new problems, especially inthe implementation phase, there are some technical constraints, so that schools as the organizers of the formal education process need energy to know and to understand the contents and objectives of the new curriculum. In the implementation technique,there arealso some constraints due to the need for adaptation to the changes from the previous curriculacommonly applied, (Qomariyah, 2014).

The procedure for entering the field of research, the researchers initially chose the location by observing the data published by the Ministry of Education and Culture (Kemendikbud). Based on these data, the researcher chose a Public High School in Sleman Regency which was stated by the Ministry of Education and Culture as the school chosen to implement the 2013 Curriculum. Researchers chose the location of Ngaglik 1 Public High School because itis a school that has adopted an approach Scientific in Sleman Regency and it has never yet been used as research location by any researchers.Based on the information obtained by the researchers, the location of the study was in accordance with the criteria that must be chosen, namely state public schools, A-accredited, choosing sub-district representatives, namely Ngaglik and far from the city center, and using the 2013 curriculum.Furthermore, the researcher consulted it to the supervisor, and he agreed it.

Curriculum and learning are two things that cannot be separated from each other (Ro'iyatunisa 2013: 3). As a plan or a program, the curriculum will not be meaningful when it is not implemented in the form of learning. Vice versa, without a clear curriculum as a reference, the learning will not go on effectively.

Law Number 20 of 2003 concerning the National Education System states that the curriculum is a set of plans and arrangements regarding the content and material of the lesson as well as the methods used as guidelines for the implementation of teaching and learning activities. The content and material of the lesson itself is a composition of study material, and lessons to achieve the objectives of the implementation of the relevant education unit in the context of efforts to achieve national education goals (Wina Sanjaya, 2009).

The learning process used the constructivism paradigm. The curriculum recommends a learning with a scientific approach, a problem-based learning, or a project-based learning (Minister of Education and Culture, 2013). The learning syntax has also been established, 
which is expected to facilitate teachers in implementing learning. Therefore students will become more active and construct their own understanding to master the competences of spiritual and social attitudes, knowledge, and skills.

School is a place to study which implementation requires at least three variables that must exist, namely curriculum, teachers, and teaching and learning process. The teachers become one of the components that cannot be separated in formal education so that in this case, they must be able to follow the development of a curriculum. To create an education system that is in line with this nation, the government strives to improve the quality of education through new policies in each period, one of which is the curriculum. The Indonesian curriculum has undergone several changes in its development to the date, that is the 2013 curriculum. It aimsto develop the students' knowledge, comprehension, abilities, values, attitudes, and interests, so they can do something in the form of proficiency, skill, accuracy, and the responsible success (Mulyasa, 2014: 68).

Before the 2013 curriculum is implemented, the important thing for the government to do is to conduct a good management. It determines the success of the 2013 Curriculum implementation (Katuuk, 2014). One part to be necessarily focused in this management is socialization and dissemination. This activity is intended in order that the curriculum implementers completely understand the curriculum, so that they can carry out it properly. Mayer \& Fortner (1987) stated that intensive workshops were an effective way to ensure the utilization of the disseminated curriculum material. Another way that can be used is the development of teacher professionalism related to the curriculum (Ryder, Banner, \& Homer, 2014).

When the new curriculum is implemented, of course there are some difficulties for its development. The difficulties and the challenges commonly experienced and faced by many countries are the implementation phase, such as the teacher's additional assignments and the differences experienced during learning in the class(Cheung \& Wong, 2012), the lack of teacher's understanding for the curriculum (Park, 2008, Cheung \& Wong, 2012), and the lack of facilities (Syomwene, 2013). In addition, there are also difficulties in the implementation of learning and assessment.

The assessment system carried out by teachersis also very different from the previous curriculum, namely the application of an authentic assessment. The 2013 Curriculum assessment is regulated by the Regulation of Minister of Education and Culture, Number 81 of 2013 (Minister of Education and Culture, 2013) which was later revised to be The 
Regulation of Minister of Education and Culture, Number 104 of 2014 (Minister of Education and Culture, 2014). There are 4 competencies measured in this assessment, they arethe competencies in spiritual, social attitudes, knowledge, and skills. To measure spiritual attitudes and social attitudes, there are 4 techniques that can be used, namely observation, self-assessment, assessment among the students, and journals. To measure knowledge, there are 3 techniques that can be used, including the test, observation, and assignment techniques. Meanwhilethe skill assessment, there are 4 techniques applied, namely performance assessment, projects, products, and portfolios. These assessmentsare carried out on each basic competency by bringing together the results of the assessment of some basic competencies learned, and on all subjects in the school. Then the assessment results arequalitatively described for each student for the four competencies in all subjects.

The implementation of the authentic assessments in the new curriculum has various obstacles faced by teachers, especially by the geography teachers. Theseare caused by the lack of teacher understanding of alternative assessments (Eraslan, 2013), plan of assessment, implementation of assessments, the use of various methodsin the assessment and the time of evaluation (Lumadi, 2013), lack of teachers' understanding in conductingthe assessments, lack of resources in carrying out summative assessment and formative (Kurebwa \& Nyaruwata, 2013), resources and policies (Kankam, Bordoh, Eshum, Bassaw, \& Korang, 2014).

As the 2013 Curriculum is carried out, information is needed about the teachers' barriers in implementing it, especially for geography subjects. This information can be used as input for the policy makers therefore the implementation of the curriculum becomes better and more efficient. In this regard, this study aims to describe the constraints of developing the geography teacher learning tools for SMA N 1 Ngaglik.

\section{The Methods}

The research on the constraints of Geography Education Teachers of Ngaglik 1 Public High School in Ngaglik District is a descriptive study with a qualitative approach. Descriptive research according to Sukardi (2005: 157) "is a study that attempts to describe and interpret objects according to what they are." While qualitative methodology is a research procedure that produces qualitative descriptive data in the form of written or oral words from people and observed behavior (Andi Prastowo, 2012: 22). 
Research subjects were determined using purposive techniques. Sugiyono (2007: 299) revealed that "purposive technique is a technique of determining data sources with specific considerations and objectives." Considerations in determining research subjects were geography teachers of Ngaglik 1 Public High School in Ngaglik District who had attended 2013 Curriculum education training. the snowball method is carried out in a chain manner, the technique of determining the sample which is initially small and then enlarges. Data collection methods used in this study were interviews, observation and documentation. Analysis of the data used in this study is descriptive qualitative, Sugiono (2013: 338) states that data reduction, data presentation, and conclusions. The time of the study will be carried out starting in March - July 2018.

The population in this study consisted of two geography subject teachers of Ngaglik 1 Public High School (SMA N 1 Ngaglik), meanwhile the samplesconsisted ofone Principal, three peer teachers, and two students of the school. Generally, the research steps were carried out in three phases, namely the preparation phase, the implementation phase, and the data analysis phase. Data collection technique was a systematic procedure of standard data to obtained the required data. The researcher used a qualitative approach using data collection as follows: observation, interviews, and documentation.

The data collecting used Triangulation techniques combining observation and interviews. Stainback (1988) and Sugiyono (2013: 241) stated that the techniques did not aim to determine the truth about some social phenomena, but the purpose of triangulation was to increase one's understanding of whatever was being investigated. It meant thatthe triangulation aimed to improve the researcher's understanding about the social phenomena and to investigate whether the information obtained from informants / participants is either true or wrongbased on thetheory and law.

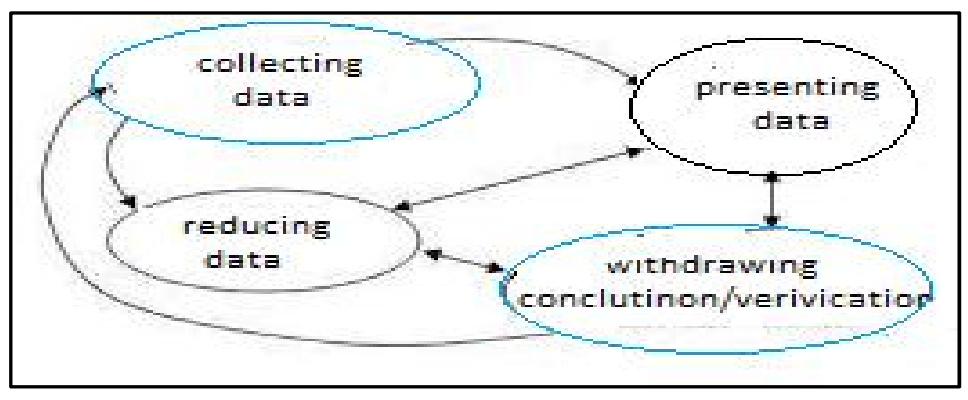




\section{Result and Discussion}

3.1 Constraints faced by teachers in developing The 2013 Curriculum learning devices in SMA N 1 Ngaglik,2017/2018 Academic Year

The development of learning devices is certainly not without constraints. The preparation of the syllabus can be completed properly, but there aresome obstacles due to the time inconsistency in the field. Both syllabus and RPP arethe guideline of teaching,but theobstacles are still found, that is making the learning implementation plans. The geography teacher at SMA N 1 Ngaglik makes the plans once a week or one semester. This is done because the geography teacher has the task burden and obligation of teaching assignments and the other ones.

The geography teacher at SMA N 1 Ngaglik has attempted to develop learning media. However the teachers have the limited time to create learning media so that teachers only develop simple learning media according to their needs and abilities. The attachment to the Minister of Education and Culture Regulation Number 103 of 2014 concerning Learning in Primary and Secondary Education explains as follows;

“... The learning process requires a carrying capacity in the form of the availability of learning facilities and infrastructure. These include furnitures, educational equipment, educational media, books and other learning resources".

The teacher has used an interactive learning model. The selection of models in which the applied methods, approaches and strategies shouldbe adapted to the material being taught. The constraints faced by one learning model are not applied in all subject matter. The selection of learning models with learning materials is what sometimes makes the teacher experience difficulties in determining the learning model.

\subsubsection{Annual Program}

The annual program is a plan to determine the time allocation for one school year to achieve a predetermined standard of competence and basiccompetences. The results of observations, andinterviews showed that the geography teachers at SMA N 1 Ngaglik was able to develop the annual program. Based on the results of the annual program analysis 
indicated that the teacher preparedthe annual program by determining the identity of learning, mentioning the points of the material to be discussed, formulating the basic competencies and estimating thelength of time based on the school calendar. The geography teacherswerebasically able to develop well the annual program.

\subsubsection{Semester Program}

Based on the results of the semester program observations showed that the teachers developed well the semester program but it was not optimal because it had not completed the specified components. The lack ofthe semester program are not yet formulating learning objectives, writing down learning resources, and determining the assessment systems. This could be seen in the semester program learning devices that had been analyzed by researchers. Based on the observations showed that geography teachers were not good enough in developing the semester program.

\subsubsection{Syllabus}

Syllabus is a product of curriculum development as a written plan that must be related to other curriculum products, namely the learning process. Teacher is an important component in education efforts. The geography teachers at SMA N 1 Ngaglik used a syllabus from the government and still develop the scientific knowledge and could be seen from the analysis of the geography syllabus. The development of the geography syllabus in SMA N 1 Ngaglik was adjusted to the potencies of school resources and thestudents. The research concluded that the development of the geography syllabus was goodenough and still in the process of improvement.

\subsubsection{Learning Implementation Plan}

Learning Implementation Plan is a plan of learning activities arranged for one meeting or more and refers to syllabus. It is developed from syllabus which aimed to direct a teacher in an effort to achieve the basic competencies (KD). It is developed by the geography teacher of SMA N 1 Ngaglik has been good enough even though it still does not meet the components determined by the government, namely the objectives and learning material have not yet been poured. The teacher is not yet capable enough in developing the plan which is of course according with the potential of student resources and school infrastructure. Based on the 
observation results of RPP geography adapted to the conservation assessment table, researchers indicated that the lesson plans were good enough.

\subsubsection{Learning model}

Based on the results of observations and interviews with respondents showed that the geography teacher at SMA N 1 Nggalik had been capable in choosing the learning model. This was stated by the principal. The teacher has already chosen a model that was of course adapted to the material because whatever the model was, learning continually runand the material could be conveyed to students. The learning model that was often used by teachers were inquiry and project.

\subsubsection{Instructional Media}

The geography teacher at SMA N 1 Ngalik has practically developed several classifications of learning media

Table 1. The Developed Several Classifications of Learning Media

\begin{tabular}{|c|c|c|}
\hline Group of Media & Learning Media & Teaching Aids \\
\hline 1. Audio & $\begin{array}{l}\text { Audio tape (open reel, } \\
\text { cassette tape) }\end{array}$ & Telephone, Intercom \\
\hline $\begin{array}{l}\text { 2. Print Material } \\
\text { (includingpictures / } \\
\text { photos) }\end{array}$ & $\begin{array}{l}\text { Programmed text, } \\
\text { manuals, modules, } \\
\text { manuals or } \\
\text { instructions }\end{array}$ & $\begin{array}{l}\text { Hand out, blackboard, } \\
\text { graphics, transparency, map, } \\
\text { globe }\end{array}$ \\
\hline 3. Projected image & $\begin{array}{l}\text { Slide, film strip (can } \\
\text { be accompanied by } \\
\text { narration or } \\
\text { explanation) }\end{array}$ & $\begin{array}{l}\text { Slides, transparencies, film } \\
\text { strips }\end{array}$ \\
\hline $\begin{array}{l}\text { 4. Audio-print } \\
\text { (combination } 1 \\
\text { and 2) }\end{array}$ & $\begin{array}{c}\text { Worksheets } \\
\text { Accompanied by tape, } \\
\text { maps or diagrams } \\
\text { accompanied by } \\
\text { narration }\end{array}$ & $\begin{array}{l}\text { Worksheets are accompanied } \\
\text { by tape, maps or diagrams } \\
\text { accompanied by narration }\end{array}$ \\
\hline $\begin{array}{l}\text { 5. Projected Audio } \\
\text { visual }\end{array}$ & $\begin{array}{l}\text { The film strip given a } \\
\text { narrative, sound slide }\end{array}$ & - \\
\hline 6. Moving image & Movie without sound & Movie without sound \\
\hline $\begin{array}{l}\text { 7. Pictures or sound } \\
\text { films }\end{array}$ & $\begin{array}{l}\text { Voice film, video-tape, } \\
\text { audio-vision (video } \\
\text { accompanied by props } \\
\text { of real objects) }\end{array}$ & Video tape \\
\hline 8. Object or things & $\begin{array}{l}\text { Real objects, models } \\
\text { or imitation objects }\end{array}$ & $\begin{array}{c}\text { Specimens, real objects, } \\
\text { models or imitation of objects. }\end{array}$ \\
\hline
\end{tabular}


This media was developed by the teacher and it had to be suitablewith the material and class conditions because these were different each other.According to the conservation tablecould be calculated that the teacher's ability to develop learning media was good enough because the teacher had tried to create the media with limited school conditions.

\subsubsection{Teaching Materials}

Teachers developedthe teaching materials such as Student Worksheets (LKS), dictates, audio-visual teaching materials. They also used the internet and library book facilities and they can beaccessed by students to study.

Table 2. The Types of Media

\begin{tabular}{|c|c|c|}
\hline & types & description \\
\hline $\begin{array}{l}\text { Printed } \\
\text { material }\end{array}$ & $\begin{array}{l}\text { handouts, module books, student } \\
\text { worksheets, brochures, leaflets }\end{array}$ & $\begin{array}{l}\text { written printing material in the form } \\
\text { of sheets folded but turned off or } \\
\text { sewn), wallcharts (printed material } \\
\text { is usually in the form of a cycle or } \\
\text { process chart or graph that means to } \\
\text { show a particular position), photos } \\
\text { or pictures, models or models }\end{array}$ \\
\hline $\begin{array}{l}\text { Printed } \\
\text { material } \\
\text { (audio) }\end{array}$ & $\begin{array}{l}\text { cassettes, radios, phonograph } \\
\text { record, and compact audio disks. }\end{array}$ & $\begin{array}{l}\text { Radio is an electronic equipment } \\
\text { that can be used to listen to good } \\
\text { and actual news, can find out } \\
\text { several important and new events } \\
\text { and events, life problems and so on. } \\
\text { Radio can be used as a learning } \\
\text { media that is quite effective }\end{array}$ \\
\hline $\begin{array}{l}\text { Teaching } \\
\text { material } \\
\text { (audio } \\
\text { visual) }\end{array}$ & compact disk, film. & $\begin{array}{l}\text { a learning model that focuses on } \\
\text { teaching and problem solving skills, } \\
\text { followed by strengthening skills (K. } \\
\text { L. Pepkin, 2004: 1). By using this } \\
\text { learning model, it expected that it } \\
\text { can increase the interest as well as } \\
\text { creativity and motivation of } \\
\text { students in learning mathematics, } \\
\text { so that students can get maximum } \\
\text { benefits both from the process and } \\
\text { the results of their learning. }\end{array}$ \\
\hline $\begin{array}{l}\text { Interactive } \\
\text { teaching } \\
\text { material }\end{array}$ & interactive compact disk & \\
\hline
\end{tabular}

The teacher's ability from a number of respondents' opinions stated that in evaluating and evaluating the results of geography learning it was very difficult to be able to formulate the objectives of the assessment and implementation. This is because the government has 
determined an assessment plan that includes attitudes, knowledge, and skills. This assessment many complain of many aspects that must be assessed. The development of learning devices that is an obligation of a professional teacher is in fact inseparable from various obstacles. It is one of the obstacles faced by geography teacher.

Geography teacher of SMA N 1 Ngaglik overcomes the obstacles in developing 2013 curriculum-based learning tools through several ways including; (1) Discussing and sharing with other geography teachers or with more senior geography teachers took part in Subject Teacher Discussion activities (MGMP) from the school, sub-district, to district levels, attendingthe trainings or workshops to add insight and various information to improvement in developing learning devices, (2) Managing the time allocation to be more effective. The teachers designedthe group assignments. The teachers expected that each member of the groups can exchange information and it can be easily understood by students so that the spent time can be effective, (3) The teacher prepares learning media in the form of power points and student worksheets. the teacher revealed that power point media is easier to use as a learning medium by making material points.

Teachers need to have the ability to design and implement the various learning strategies that are considered suitable with their interests and talents and with the level of development of students, including the usage of the various learning resources and learning media (Sanjaya, 2010: 274). (4) Besides using the wi-fi facility as a supporter of internet learning resources, the teachers can use other learning resources such as textbooks. Teachers also provide group assignments so that group members can exchange information. The teacher as a facilitator should be able to cultivate the useful learning resources and support to achieve the goals of the teaching and learning processes, (4) Explaining to the point of one way to overcome the difficulties of the teacher in "reasoning" and "presenting". In accordance with the professionalism of the teachers, they must have the ability to manage the classes, andthe teaching and learning interactions. They must explain clearly the materials in order to be easily understood by the students. It is the basis for the teacher to convey to the point, therefore the delivery of the subject is easily accepted by students and hey can understand the intent and purpose of the learning.

\section{Conclusion}

The problems encountered by the geography teachers of SMA Negeri 1 Ngaglik included: developing the learning devices,composing the syllabus using the scientific 
approach,implementing the learning models according to the 2013 curriculum. In addition, they hadsome difficulties in developing learning media,providing the teaching materials, and making the attitude and skill assessments. The teachers overcamethe difficulties of developing the learning toolsby discussing and sharing with other geography teachers or with geography teachers who have been senior, participating in Subject Teacher Discussion activities (MGMP) from the school, sub-district, to Regency levels, must attend thetraining or the workshops to add insight and various information for improving the development of 2013 curriculum learning devices.

\section{References}

Cheung, A.C.K \& Wong, P.M. (2012). "Factors Affecting the Implementation of Curriculum Reform in Hong Kong: Key Findings from a Large Scale Survey Study". International Journal of Educational Management, Vol. 26 Iss: 1, pp.39 - 54. Doi: http://dx.doi.org/10.1108/09513541- 211194374.

Eraslan, A. (2013). “Teachers' Reflections on the Implementation of the New Elementary School Mathematics Curriculum in Turkey”. HU Journal of of Education. 28 (2), 152165.

Mulyasa. E (2014). Pengembangan dan Implementasi kurikulum 2013. Bandung: PT. Remaja Rosdakarya.

Kankam, B., Bordoh, A., Eshum, I., Bassaw, T.K, \& Korang, F.Y. (2014). 'Teachers' Perception of Authentic Assessment Techniques Practice in Social Studies Lessonsin Senior High Schools in Ghana”. International Journal of Educational Researchand Information Science. 1 (4): 62-68.

Katuuk, D.A. (2014). Manajemen Implementasi Kurikulum: Strategi Penguatan Implementasi Kurikulum 2013. Cakrawala Pendidikan, 13 (1): 13-26.

Kurebwa, M. \& Nyaruwata, L.T. 2013. ”Assessment Challenges in the Primary Schools: A Case of Gweru Urban Schools". Greener Journal of Educational Research 3(7), pp. 336344.

Lumadi, M.W. (2013). "Challenges Besetting Teachers in Classroom Assessment: An Exploratory Perspective”. Journal of Social Science. 34 (3): 211-221. 
Mayer, V.J. \& Fortner, R.W. (1987). "Relative Effectiveness of Four Modes of Dissemination of Curriculum Materials", TheJournal of Environmental Education, 19(1) 25-30. Doi:10.1080/00958964.1987.- 10801957.

Menteri Pendidikan dan Kebudayaan Republik Indonesia. (2013). Peraturan Menteri Pendidikan dan Kebudayaan Nomor 81 Tahun 2013 tentang Pelaksanaan Penilaian.

Menteri Pendidikan dan Kebudayaan Republik Indonesia. 2014. Peraturan Menteri Pendidikan dan Kebudayaan Nomor 104 Tahun 2014 tentang Pelaksanaan Penilaian.

Ryder, J., Banner, I., \& Homer, M. (2014). “Teachers' Experiences of Science Curriculum Reform". School.

Sugiyono. (2007). Metode Penelitian Kuantitatif Kualitatif dan R \& D. Bandungan: Alfabeta.

Sukardi. (2005). Metodologi Penelitian Pendidikan Kompetensi dan Praktiknya. Jakarta: Bumi Aksara.

Syomwene, A. (2013). "Factors Affecting Teachers' Implementation of Curriculum Reforms and Educational Policies in Schools: The Kenyan Experience”. Journalof Education and Practice. 4 (22) 80- 86.

Wina Sanjaya. (2010). Perencanaan \& Desain Sistem Pembelajaran. Jakarta: Kencana.

Qomariah. (2014). Kesiapan Guru dalam Menghadapi implementasi kurikulum 2013. Semarang; Mahasiswa pendidikan Ekonomi IKIP Veteran Semarang. 